\title{
Application of Métier-Based Approaches for Spatial Planning and Management: A Case Study on a Mixed Trawl Fishery in Taiwan
}

\author{
Yi-Jou Lee ${ }^{1}$, Nan-Jay Su ${ }^{1,2,3}$, Hung-Tai Lee ${ }^{1}$, William Wei-Yuan Hsu ${ }^{4}$ and Cheng-Hsin Liao ${ }^{1,2, *}$ \\ 1 Department of Environmental Biology of Fisheries Science, National Taiwan Ocean University, \\ Keelung 20224, Taiwan; li00131022@gmail.com (Y.-J.L.); nanjay@mail.ntou.edu.tw (N.-J.S.); \\ hungtailee@gmail.com (H.-T.L.) \\ 2 Center of Excellence for the Oceans, National Taiwan Ocean University, Keelung 20224, Taiwan \\ 3 Intelligent Maritime Research Center, National Taiwan Ocean University, Keelung 20224, Taiwan \\ 4 Department of Computer Science and Engineering, National Taiwan Ocean University, \\ Keelung 20224, Taiwan; wwyhsu@mail.ntou.edu.tw \\ * Correspondence: chliao@mail.ntou.edu.tw; Tel.: +886-224-622-192
}

Citation: Lee, Y.-J.; Su, N.-J.; Lee, H.-T.; Hsu, W.W.-Y.; Liao, C.-H. Application of Métier-Based Approaches for Spatial Planning and Management: A Case Study on a Mixed Trawl Fishery in Taiwan. J. Mar. Sci. Eng. 2021, 9, 480. https:// doi.org/10.3390/jmse9050480

Academic Editor: Anna Nora Tassetti

Received: 10 April 2021

Accepted: 27 April 2021

Published: 29 April 2021

Publisher's Note: MDPI stays neutral with regard to jurisdictional claims in published maps and institutional affiliations.

Copyright: (C) 2021 by the authors. Licensee MDPI, Basel, Switzerland. This article is an open access article distributed under the terms and conditions of the Creative Commons Attribution (CC BY) license (https:// creativecommons.org/licenses/by/ $4.0 /)$.

\begin{abstract}
Mixed fisheries refer to fishing activities that catch more than one species simultaneously, and a species may be fished using different gear. A trawl fishery shares these features to exploit multiple species simultaneously, with diverse fishing gear and strategies. The situation becomes more complex when interactions among fleet dynamics, fishing activities, and fishery resources are involved and influence each other. Information regarding the operational patterns may be hidden in a set of long-term big data. This study aims to investigate the fishery structure and fleet dynamics of trawl fisheries in Taiwan for spatial planning and management, based on a long-term dataset from a management system that collects information by using voyage data recorders (VDR) and dockside observers. We applied a two-step data mining process with a clustering algorithm to classify the main groups of fishery resources and then identified 18 catch métiers based on catch composition. The target species, operation pattern, and fishing season were determined for each métier, and associated with the relevant fishery resources and the fishing gear used. Additionally, fishing effects on target species were estimated using information on fishing grounds and trajectories from VDR. The métier-based approach was successfully applied to define the six major fishery resources targeted by trawlers. We examined the key features of fishing activity associated with catch composition and spatial-temporal fishing metrics, which could be used to provide suggestions for the spatial planning and management of the mixed trawl fishery in the offshore waters of Taiwan.
\end{abstract}

Keywords: mixed fisheries; multispecies; data mining; métier-based approaches; spatial planning and management; voyage data recorder

\section{Introduction}

Coastal and offshore fisheries play an important role in providing a protein source and economic development, particularly for countries that depend on marine resources [1,2]. However, these countries urgently need environmental conservation, because their fishery resources are threatened by overfishing, pollution, and habitat destruction [3,4], which emphasizes the need for suitable management measures and sustainable use of fishery resources [5-7].

Located in the south of the East China Sea and on the edge of a continental shelf (Figure 1), Taiwan has rich marine bio-resources and biodiversity in its surrounding waters, with multiple types of habitats. More than 20 fishery sectors exist in this area, including historical native fishing activities and new fishing methods introduced from Japan and Europe [8]. As the second largest fishery in the coastal and offshore waters, the Taiwanese trawl fishery operates mainly within exclusive economic zones (EEZs). This 
fishery provides marine food products stably for domestic consumption, accounting for $19.4 \%$ and $28.1 \%$ of the coastal and offshore fisheries over the last decade, respectively [9]. However, catches from coastal and offshore trawling have declined shapely over the past 30 years. The trawl fishery has always been argued to be damaging the benthic habitat and overexploiting the fishery resources $[10,11]$. Therefore, to overcome this issue, a management approach was implemented to reduce fishing and vessels during the 1990s and the 2000s [12-14].

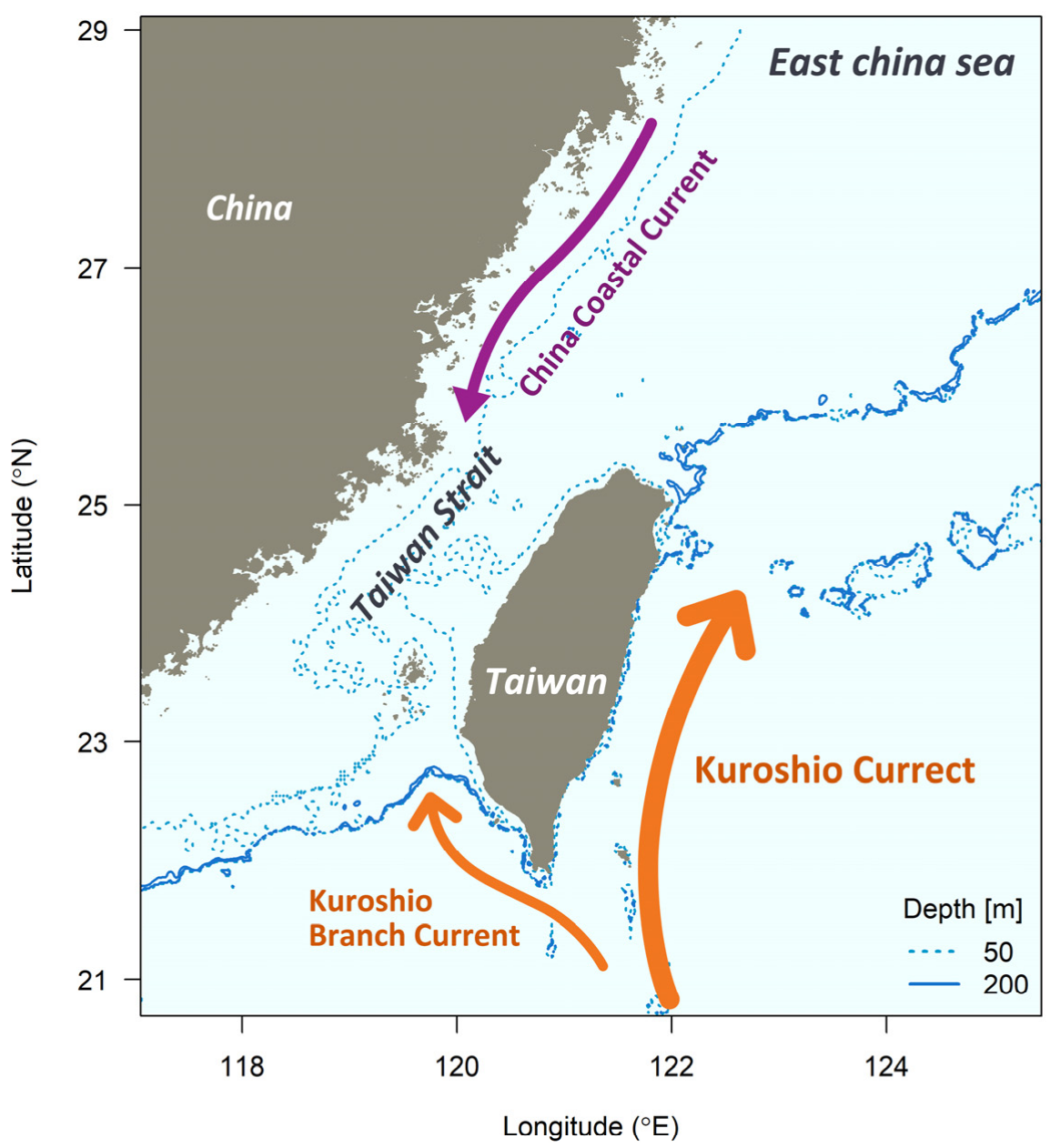

Figure 1. Map showing the study area and major currents surrounding Taiwan.

Another important management measurement for trawling is to restrict the operations to within 3 nautical miles from the coast lines and also the use of rollers or rockhopper gear in the trawling nets. Trawling vessels under 50 GRT are not allowed to fish in areas between 3 and 12 nautical miles from the coast lines [15]. Both artisanal (small-scale) and large-scale trawl fisheries present complex characteristics in their gear and harvest species, which involve interactions among biology, fisheries, economy, and society, and result in the complicated, mixed structure of the trawl fisheries [16-21]. The situation worsens when diverse fishing types are developed, such as otter trawling, pair trawling, the pelagic pair trawling of larval anchovy, and shrimp trawling, including sakura shrimp and the Taiwan mauxia shrimp trawlers; moreover, there is a lack of information about the stakeholders, fishery resources, and the fishing operations [22].

Comprehensive understanding of coastal trawl fisheries in Taiwan is extremely limited; only analyses on a small spatial scale, a single type of fishing gear, or short time period are currently available $[2,12,20]$. A métier-based approach has the ability to integrate the main components of the fleet dynamics, fishing activities, and harvest, by providing a full picture of the fishery structure, to achieve the sustainable development of fishery management. 
Numerous studies have demonstrated that métier characteristics, such as fleet dynamics, catch composition, and fishing strategy, can be used to classify fishery structure [23-25]. For example, a fishing strategy was classified to determine the fleet capacity and the fishing activities of a similar catch composition, in order to indicate targets [26-32]. This is potentially useful in revealing the fishing strategy and the fishermen's behavior by integrating the social and economic variables, fishing patterns, and spatial and temporal information [6,19,21,33-37]. A mixed fishery (such as the trawl fisheries) could be better described by grouping similar features (i.e., métiers) through the exploration of the fishery structure. Hence, the métier has been used to plan fishery policy and management measures for mixed fisheries, particularly for coastal and offshore waters [38-42].

Coastal and offshore fisheries have been developed and well managed in Taiwan. This provides a great opportunity to examine the fishery information and catch composition from landing data, along with geo-information obtained from voyage data recorder (VDR) trajectories for mixed complex trawl fisheries. For the development of an ecosystem-based fishery management for the future, all the available information collected from trawl fisheries should be integrated into a management system.

The objectives of this study were to understand the fishery structure and fleet dynamics of trawl fisheries in Taiwan, based on a long-term dataset (2013-2019) from a management system that collects information by using VDRs and dockside observers. We classified the fishermen's behavior and fishing patterns, which changed by season, gear type, and the captain's experience. Through the development of a métier-based approach, based on a data mining process, we identified the catch compositions and defined the catch métier on the basis of the integrated data from the VDR trajectories, to infer the spatial distribution of the fishing fleet and, thus, the fishery resources. The results from this study could be used to suggest possible management units and measures for trawl fisheries in coastal and offshore waters.

\section{Materials and Methods}

\subsection{Data Used}

The two datasets used in this study were obtained from the VDR system and a port sampling observer program managed by the Fisheries Agency from 2010 and 2007, respectively $[2,12,15,22]$. The VDR is a global position system (GPS)-based vessel trajectory recording system that records operation dates, vessel positions, speeds, and heading angles every $3 \mathrm{~min}$, providing high-resolution tempo-spatial information of fishing vessel operating distribution. In order to monitor the coastal fisheries and their catch compositions, a dockside sampling observer program was launched at the main fishing ports around the Taiwan, Penghu, and Xiaoliuqiu islands. When the fishing vessels returned to port, this program recorded the vessel's registered number, vessel size category, days duration of the trip, gear type, fishing set, and landing by species. The landing data and operating information were classified by gear type, including otter trawl (OT), pair trawl (PT), pelagic pair trawl of larval anchovy (LA), shrimp trawl (ST), sakura shrimp trawl (SKT), and Taiwan mauxia shrimp trawl (TMT).

We matched the two datasets from the VDR system and the observer program according to the vessel registration number and the date of leaving and returning to the fishing ports. It was unreasonable to get to the fishing ground, operate, and come back to the original port within $3 \mathrm{~h}$, so this criterion was applied to exclude part of the data.

The catch for each trip was identified by species according to the Fisheries Statistical Yearbook of the Fisheries Agency, Taiwan [9]. Harvests that were difficult to identify into species were grouped; for example, several species of black sea bream were recorded as "black sea bream", and several species of hairtail were classified as "hairtail." In summary, the landing catch by the trawl fisheries operating in coastal and offshore Taiwan was classified into 153 species, within 22 target groups (Table S1).

As demonstrated in numerous previous studies [12,43-45], the speed criterion was used for identifying fishing activity or cruising in trawl fisheries. We then estimated 
the fishing process on the basis of the threshold of the vessel fishing speeds [22], with auxiliary information from the VDR data (Table S2) for visualizing the footprint distribution. The spatial distribution of the fishing process in an hour was presented in $0.1^{\circ} \times 0.1^{\circ}$ square grids.

\subsection{Analysis Based on Catch Métier}

Clustering analysis is a popular and widely used data mining technique for capturing the common characteristics within data [46]. In fisheries science, this method helps to understand and describe the characteristics of mixed fisheries on the basis of the métier concept and analyze the catch composition and fishing patterns [21,25-29]. To examine the operation pattern in trawl fisheries, we grouped the trips that were similar in catch composition by using cluster analysis and then defined the catch métier. The proportion of the landing by species was calculated for each trip and then used in the analysis $[6,28,33]$. For each group of catch métiers, a data matrix was presented to show the fishing trip (by row) and the target group or landing by species (by column).

A two-step clustering approach was then applied to further reduce and illuminate the complexity of catch species for the trawl fisheries in Taiwan. The first step was to cluster the fishing trips by the target group from 22 categories with low-resolution information, to reveal the specific fishery resources; the second step was to cluster the catch compositions with high-resolution information at a species level. A hierarchical agglomerative cluster (HAC) analysis was applied in this data mining process by using the "hclust" function, based on the Euclidean distance and Ward's grouping algorithm in the statistical software $\mathrm{R}[47,48]$. Optimal numbers of clusters were determined and combined using the Elbow method and further tested statistically using ANOSIM [49], which measures the similarities between and within clusters by using the "vegan" package in R.

\section{Results}

\subsection{Fishery Structure}

In total, 251,569 fishing trips were collected from 1,132 trawlers, as obtained from the dataset that combined the two sources of data (Figure S1), with records of the vessel size category indicating that mid-size vessels (10-99 GRT) accounted for $82 \%$ (Table 1 ). The proportion of small-scale fishing craft $(<10$ GRT) and large-scale vessels was $12 \%$ and $6 \%$, respectively. As expected, large-scale fishing vessels were more productive than smallscale ones. Otter trawling was widely used for six different trawl gears of the mid-scale vessels. A part of the mid-scale vessels targeted shrimps or sakura shrimp (Lucensosergia lucens) and Taiwan mauxia (Acetes intermedius). The small-scale fishing rafts targeted miscellaneous shrimp. The pair trawl and pelagic pair trawl mid- and small-scale vessels targeted larval anchovy.

Table 1. Summary of the sampled fishing vessels and catches by trawl fishing gear and vessel size.

\begin{tabular}{|c|c|c|c|c|c|c|c|c|c|}
\hline \multirow{2}{*}{\multicolumn{2}{|c|}{ Vessel Size $^{1}$}} & \multirow[b]{2}{*}{ OT } & \multicolumn{5}{|c|}{ Fishing Gear (\% of All Vessels) } & \multirow{2}{*}{$\begin{array}{l}\text { Number } \\
\text { of Vessel }\end{array}$} & \multirow{2}{*}{$\begin{array}{c}\text { Catches } \\
\text { (ton) }\end{array}$} \\
\hline & & & PT & LA & ST & SKT & TMT & & \\
\hline \multirow{4}{*}{ Small } & CTR & 0.8 & 11.9 & 10.5 & 9.5 & - & - & 102 & 2720 \\
\hline & СТ0 & 0.5 & - & - & 0.9 & - & - & 11 & 8 \\
\hline & CT1 & 0.8 & - & 1.3 & 1.9 & 0.8 & 0.8 & 22 & 173 \\
\hline & CT2 & 5.9 & 8.6 & 36.8 & 4.9 & 3.0 & 6.4 & 114 & 5163 \\
\hline \multirow{2}{*}{ Middle } & CT3 & 53.6 & 50.3 & 50 & 6.8 & 80.9 & 84.8 & 530 & 58,393 \\
\hline & CT4 & 30 & 28.1 & 1.3 & 3.2 & 12.7 & 6.4 & 286 & 21,402 \\
\hline \multirow{3}{*}{ Large } & CT5 & 6.5 & 1.1 & - & 0.1 & 2.5 & 1.6 & 52 & 4531 \\
\hline & СT6 & 1.9 & - & - & - & - & - & 15 & 2993 \\
\hline & total & 780 & 185 & 76 & 213 & 236 & 125 & 1132 & 95,384 \\
\hline
\end{tabular}

${ }^{1}$ Size categories indicating the gross register tonnage (GRT) for the Taiwanese vessels: CTR for fishing craft, CT0 for $<5$ GRT, CT1 for 5-9 GRT, CT2 for 10-19 GRT, CT3 for 20-49 GRT, CT4 for 50-99 GRT, CT5 for 100-199 GRT, and CT6 for 200-499 GRT. 
The structure of coastal and offshore trawl fisheries in Taiwan consisted of mid-scale otter trawler. Diverse trawl gears were used in small-scale vessels. Fishermen changed their fishing gear within the specified period, as observed in $31 \%$ of all sampled vessels (351 vessels).

\subsection{Catch Métier}

From the first step analysis results of HCA clustering, six target groups were determined by the dendrogram and the scree plot of the variance within the clusters (Figure 2 and Figure S2), as well as the ANOSIM test with the R statistic value of 0.555 (Figure S3a). The determination of the number of clusters and the examination process are shown in Table S3 and Figure S4. The main characteristics of each target group composition (Clusters I-VI) are shown with boxplots in Figure 2 and Table 2. There was a variance in the catch weight ratio of the target group of each cluster, indicating the difference among the fishing trips.

(a)

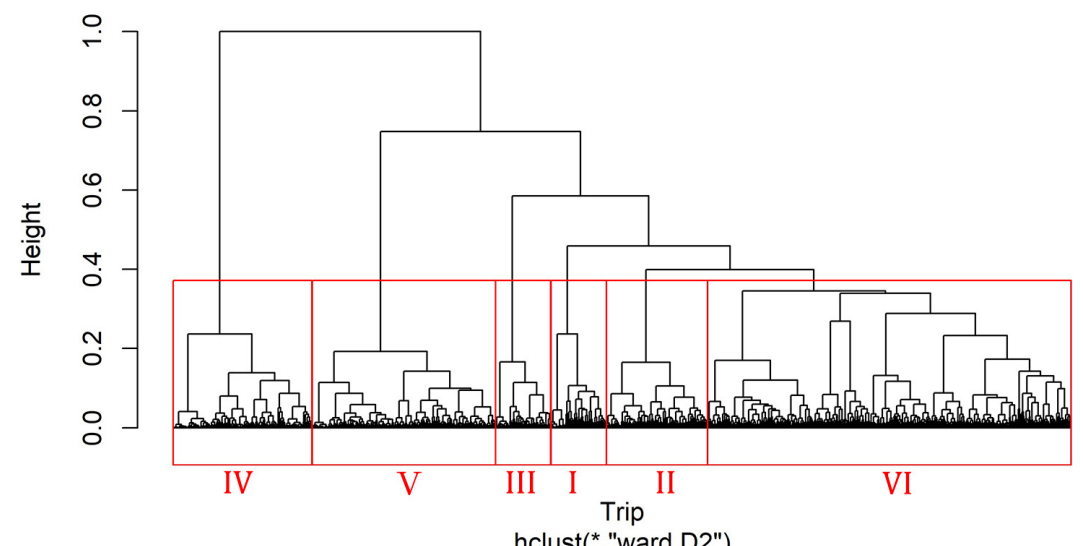

(b)
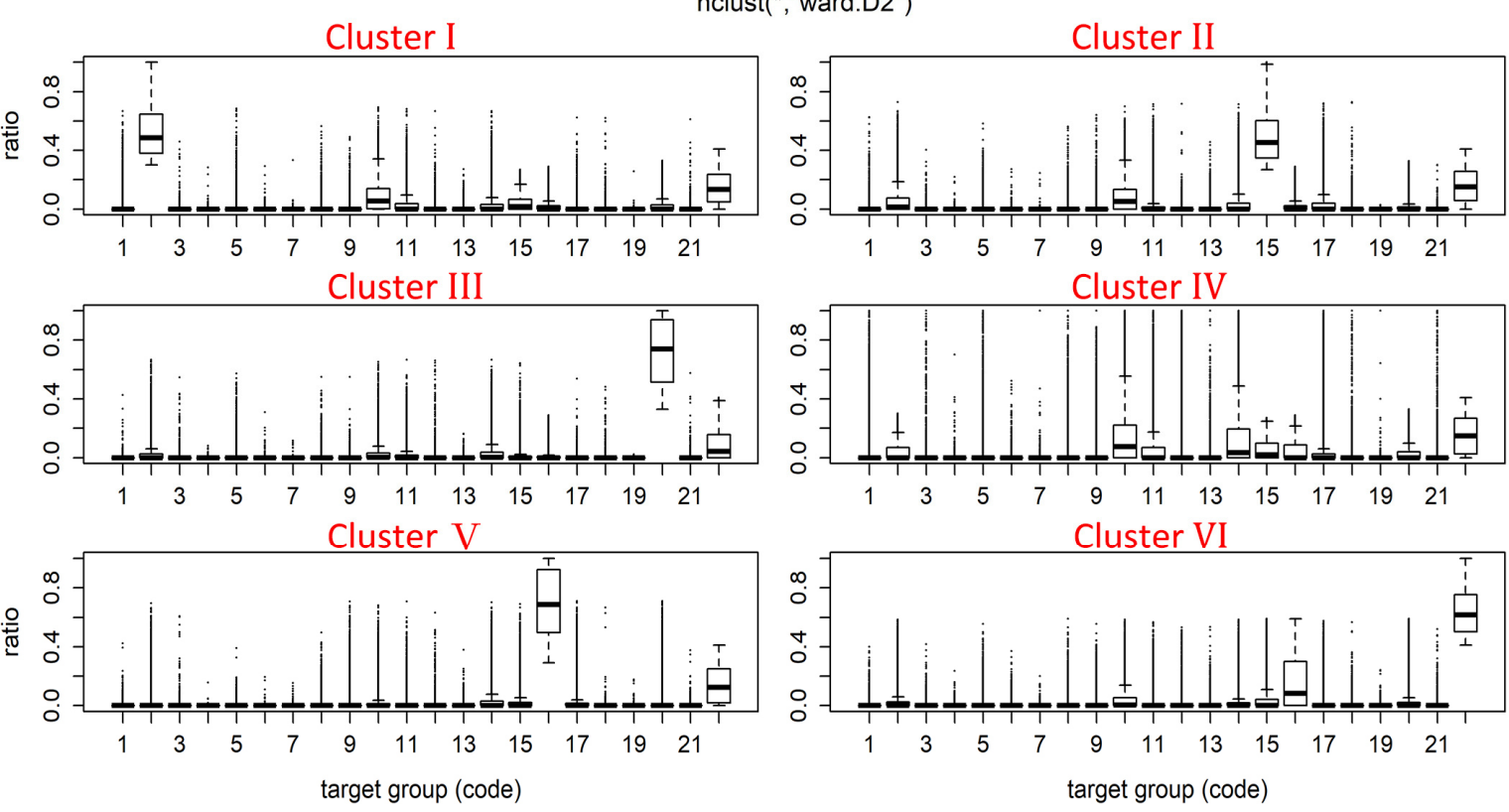

Figure 2. Hierarchical clustering dendrogram (a), and the six clusters (b), showing the main target group in catch composition for the trawl fishery. The ratios in catch weight are shown in boxplots as inferred from the landing data for each trip. 
Table 2. Composition characteristics classified from two-step clustering and into 18 defined catch métiers, which indicate the different fishing patterns (gray block). The most frequent target species in each catch métier trips are presented, with average catch weight in proportion.

\begin{tabular}{|c|c|c|c|c|c|c|c|c|c|c|c|c|c|c|c|c|c|c|}
\hline Cluster & I & II & III & \multicolumn{6}{|c|}{ IV } & \multicolumn{5}{|c|}{ V } & \multicolumn{4}{|c|}{ VI } \\
\hline Jacks and scads & 0.54 & 0.06 & 0.03 & & & & & & & & & 0.01 & & & & 0. & & \\
\hline $\begin{array}{r}\text { Seabream and } \\
\text { snapper }\end{array}$ & 0.09 & 0.09 & 0.03 & & & & & & & & & 0.02 & & & & & & \\
\hline Croakers & 0.03 & 0.04 & 0.04 & & & & & & & & & 0.03 & & & & & & \\
\hline Cephalopods & 0.05 & 0.51 & 0.02 & & & & & & & & & 0.02 & & & & 0. & & \\
\hline Hairtails & 0.03 & 0.02 & 0.72 & & & & & & & & & 0.01 & & & & & & \\
\hline Shrimps & 0.03 & 0.03 & 0.02 & & & & & & & & & 0.69 & & & & 0. & & \\
\hline Misc. & 0.15 & 0.16 & 0.09 & & & & & & & & & 0.15 & & & & 0. & & \\
\hline Catch métier & 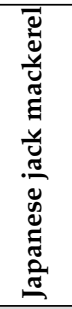 & 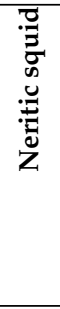 & 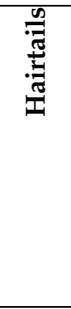 & 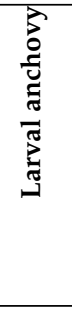 & 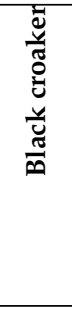 & 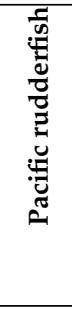 & 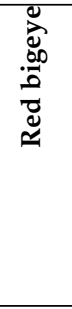 & 先 & 它 & 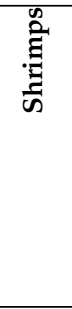 & 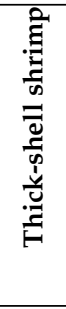 & 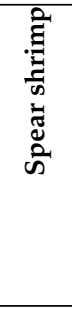 & 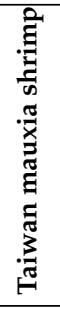 & 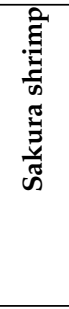 & 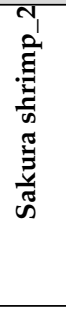 & 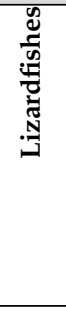 & 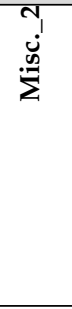 & $\begin{array}{l}m \\
\dot{0} \\
\dot{n} \\
\dot{m}\end{array}$ \\
\hline $\begin{array}{r}\text { Japanese jack } \\
\text { mackerel }\end{array}$ & 0.11 & 0.03 & - & - & - & - & - & - & - & - & - & - & - & - & - & - & - & 0.02 \\
\hline Japanese scad & 0.04 & - & - & - & - & - & - & - & - & - & - & - & - & - & - & - & - & - \\
\hline Shrimp scad & 0.03 & - & - & - & - & - & - & - & - & - & - & - & - & - & - & - & - & - \\
\hline Hairtails & - & - & 0.72 & - & 0.05 & 0.06 & 0.06 & - & 0.04 & - & - & - & - & 0.03 & 0.01 & - & - & 0.03 \\
\hline Black pomfret & 0.04 & - & - & - & 0.44 & - & - & - & - & - & - & - & - & - & - & - & - & - \\
\hline Red bigeye & - & - & 0.02 & - & 0.05 & 0.07 & 0.29 & - & - & - & - & - & - & - & - & - & - & - \\
\hline White croaker & - & - & 0.02 & - & - & - & - & - & 0.09 & - & - & 0.07 & - & - & - & - & - & - \\
\hline Black croaker & - & - & 0.02 & - & - & 0.06 & 0.09 & - & - & - & - & - & - & - & - & - & - & - \\
\hline $\begin{array}{r}\text { Pacific } \\
\text { rudderfish }\end{array}$ & - & - & 0.02 & - & 0.06 & 0.45 & 0.12 & - & - & - & - & - & - & - & - & - & - & - \\
\hline Larval anchovy & - & - & - & 0.99 & - & - & - & - & - & - & - & - & - & - & - & - & - & - \\
\hline Lizardfishes & - & 0.05 & - & - & - & - & - & - & - & & - & - & - & - & - & 0.17 & 0.05 & - \\
\hline Flatfish & - & - & - & - & - & - & - & 0.04 & - & 0.05 & - & 0.04 & - & - & - & - & 0.08 & - \\
\hline Jarbua terapon & - & - & - & - & - & - & - & - & 0.05 & - & - & - & - & - & - & - & - & - \\
\hline Porgies & - & - & - & - & - & - & - & - & 0.04 & - & - & - & - & - & - & - & - & - \\
\hline $\begin{array}{r}\text { Threadfin } \\
\text { breams }\end{array}$ & - & - & - & - & - & - & - & - & - & - & - & - & - & - & - & 0.08 & - & - \\
\hline Neritic squid & - & 0.31 & - & - & - & - & 0.04 & - & - & - & - & - & - & - & - & 0.08 & - & - \\
\hline Cuttlefish & - & 0.13 & - & - & - & - & - & 0.04 & - & - & - & - & - & - & - & - & - & - \\
\hline Octopus & - & 0.03 & - & - & - & - & - & - & - & - & - & - & - & - & - & - & - & - \\
\hline $\begin{array}{r}\text { Blue swimming } \\
\text { crab }\end{array}$ & - & - & - & - & - & - & - & 0.25 & - & - & - & - & - & - & - & - & - & - \\
\hline $\begin{array}{l}\text { Three-spot } \\
\text { swimming crab }\end{array}$ & - & - & - & - & - & - & - & 0.16 & - & - & - & - & - & - & - & - & - & - \\
\hline $\begin{array}{r}\text { Thick-shell } \\
\text { shrimp }\end{array}$ & - & - & - & - & - & - & - & - & - & 0.04 & 0.15 & - & - & - & - & - & - & - \\
\hline Red tail shrimp & - & - & - & - & - & - & - & - & - & 0.04 & 0.09 & - & - & - & - & - & - & - \\
\hline Sand shrimp & - & - & - & - & - & - & - & - & - & - & 0.06 & - & - & - & - & - & - & - \\
\hline Spear shrimp & - & - & - & - & - & - & - & - & - & - & - & 0.55 & - & - & - & - & - & - \\
\hline $\begin{array}{r}\text { Taiwan mauxia } \\
\text { shrimp }\end{array}$ & - & - & - & - & - & - & - & - & - & - & - & - & 0.95 & - & - & - & - & - \\
\hline Sakura shrimp & - & - & - & - & - & - & - & - & - & - & - & - & - & 0.74 & 0.29 & - & - & 0.03 \\
\hline $\begin{array}{r}\text { Whiteleg } \\
\text { shrimp }\end{array}$ & - & - & - & - & - & - & - & - & - & - & - & - & - & 0.06 & 0.01 & - & - & - \\
\hline $\begin{array}{r}\text { Other jack and } \\
\text { scad }\end{array}$ & 0.05 & - & - & - & - & - & - & - & - & - & - & - & - & - & - & 0.09 & 0.07 & - \\
\hline Other fish & - & - & - & - & 0.08 & 0.05 & - & 0.05 & 0.05 & 0.07 & 0.06 & 0.06 & 0.04 & 0.15 & 0.64 & 0.07 & 0.16 & 0.61 \\
\hline Other shrimp & - & - & - & - & - & - & - & - & - & 0.44 & 0.07 & 0.05 & - & 0.02 & 0.02 & - & 0.05 & 0.04 \\
\hline
\end{tabular}

Clusters I, II, and III mainly targeted jacks and scads, cephalopods, and hairtails, respectively. Their average catch proportion was more than $50 \%$. In particular, the hairtails in Cluster III reached $72 \%$. Cluster V had a high average catch of shrimp (69\%), but captured other shrimp species in this group. Similar patterns were found in Clusters $V$ and VI. Given the huge number of trips in Clusters IV, V, and VI, and their unclear and hidden 
catch information in the profile, these clusters were then further examined in the second step of the clustering analysis, with high-resolution data by species.

In all, we defined 18 catch métiers with the two-step data mining approach shown in Figure S5, and the pertinent statistic test results showed significance (R: 0.937, Figure S3b). In the first step, three métiers confirmed that fishing trips definitely targeted a similar taxonomic group of species (Clusters I-III), and the rest of the 15 métiers were classified from the second step processed on Clusters IV-VI. The results shown in Table 2 present one major species accompanied by some associated species in each catch métier, which can be observed from the composition profiles according to the average weight of catch per species and defined by the target species tendency for every métier.

The fishing patterns in Clusters I-III were dominant, and could thus be classified with low-resolution data. The trips in Cluster I mainly targeted the Carangidae species and were most abundant in Japanese jack mackerel (Trachurus japonicus); major targets of Cluster II were neritic squids (Uroteuthis spp.) and cuttlefish (Sepiidae); Cluster III was principally composed of hairtails (Trichiurus spp.).

The target group in Cluster IV was consistent, and six sub-clusters were identified from the second step of the clustering, namely larval anchovy, black croaker, Pacific rudderfish, red bigeye, crabs, and a miscellaneous composition (Misc._1). The catch métier of larval anchovy was composed of the larval stage of Japanese anchovy (Engraulis japonicus), oceanic anchovy (Encrasicholina punctifer), and short-head anchovy (Encrasicholina heteroloba). This is a traditional fishing pattern in Taiwan, so a large number of trips were distinguished.

The thick-shell shrimp (Metapenaeopsis barbata) and spear shrimp (Parapenaeus spp.) are common species in coastal and offshore waters; sakura shrimp (Lucensosergia lucens) and Taiwan mauxia shrimp (Acetes intermedius) are pelagic species and generally caught by specific trawl gear in Taiwan. There were 5 catch métier, separated in Cluster V, that target miscellaneous Shrimps, thick-shell shrimp, spear shrimp, Taiwan mauxia shrimp and sakura shrimp, showing the dominant shrimp resources in Taiwan.

Cluster VI, with a miscellaneous composition, identified a relatively high-frequency catch of lizardfishes (Synodontidae) and sakura shrimp. The catch métier of sakura shrimp_2 is most abundant catch, with a relative high percentage of sakura shrimp. This represents a specific fishing pattern that targets sakura shrimp. The rest of Cluster VI was identified as having no specific targeting of sub-clusters (Misc._2 and Misc._3).

\subsection{Fishing Performance among Catch Métiers}

The major target species revealed in each catch métier showed the trends of the fishery resources exploited in the trawl fisheries in Taiwan, with the main species being cephalopod, fish, crab, and shrimp. The number of trips within a specific catch métier and the gear used in each trip are shown in Table 3.

Neritic squids were the main harvest in summer (June to September), but the target of this cluster included hairtails, Japanese jack mackerel, black croaker, pacific rudderfish, and red bigeye, which showed peak catch in autumn and winter (October-February). The Japanese jack mackerel, black croaker, and red bigeye continued to be captured until spring (March-May). The fishing period of larval anchovy showed a peak during spring to autumn, while the lizardfishes were dominant in summer and autumn (June-October) and crabs in autumn.

Shrimps could be harvested the whole year (catch métier of shrimps and thick-shell shrimp), with specific seasons for certain species, depending on the targeting. For example, the catches of spear shrimp and sukura shrimp increased in winter and spring (NovemberMay), and the Taiwan mauxia shrimp appeared in summer and autumn (July-November).

High proportions of hairtails and larval anchovy were observed in the catch for the PT $(77.0 \%)$ and larval anchovy in the LA (97.2\%). Crabs were mainly harvested by the ST and the SKT, while the Taiwan mauxia shrimp was caught by middle-water trawl gear. The thick-shell shrimp and spear shrimp showed a similar probability of being captured by the OT and the ST. 
Table 3. Catch métier characteristics by fishing season and the main fishing gear, from the results of two-step clustering analysis. The fishing season is presented as the frequency of the trips in each catch métier. The trip percentage (\%) indicates the main fishing gear used for the trawl fishery.

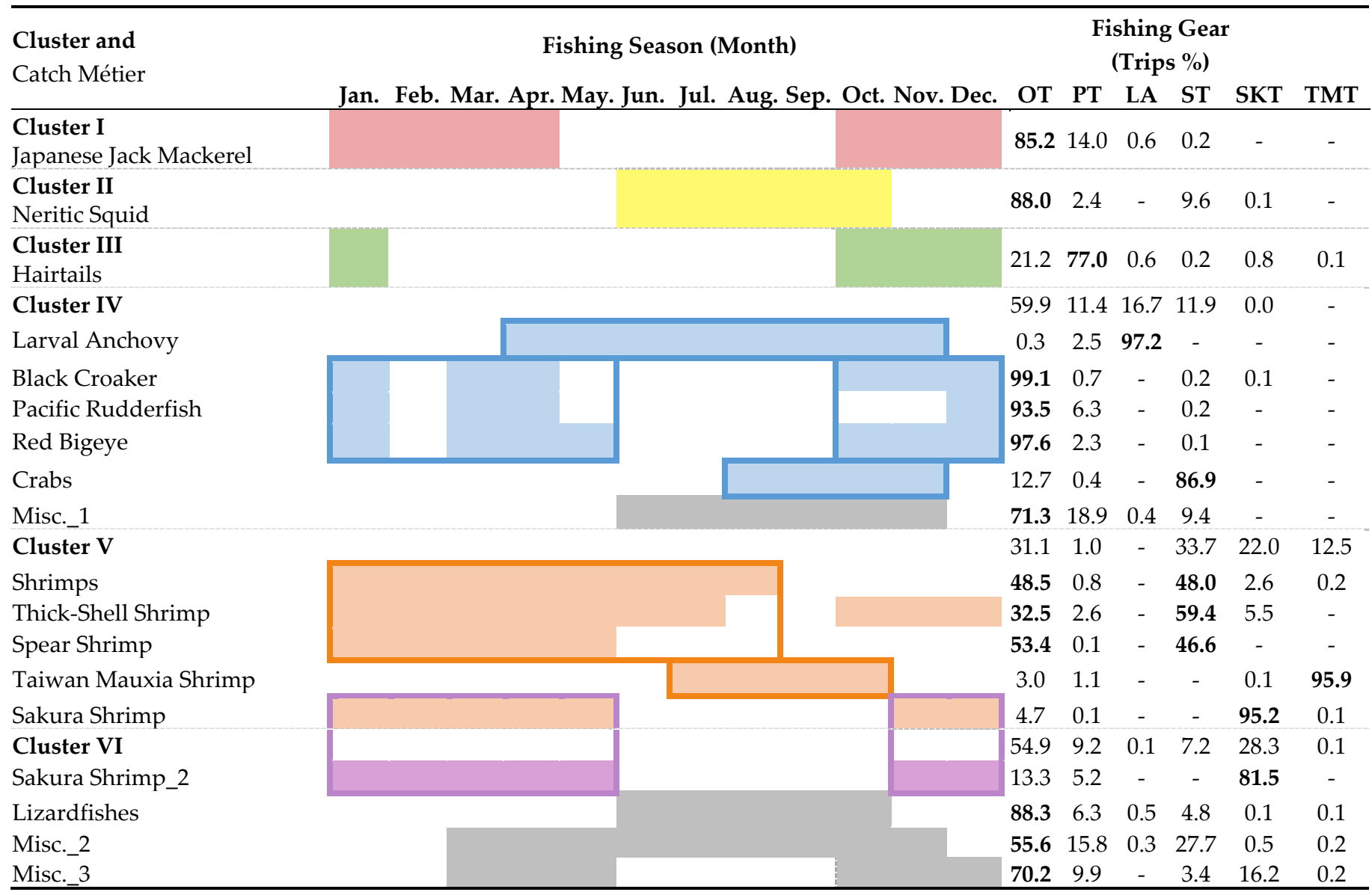

\subsection{Fishery Resources}

According to the catch amount and catch proportion (Table 4), hairtails were the main harvest species, accounting for $15.7 \%$ of the catch of the trawl fisheries. As the second species in the trawl fisheries, the Japanese jack mackerel contributed $10.5 \%$ of the total catches. In summary, hairtails, Japanese jack mackerel, sakura shrimp, neritic squids, Taiwan mauxia shrimp, and larval anchovy were the main exploited fishery resources, and accounted for $55 \%$ of the total catch in Taiwanese coastal and offshore trawl fisheries.

The estimated fishing maps from the VDR trajectory data for the catch métier are shown in Figure 3. Most of the fishing process for the trawl fisheries was distributed in waters off northeastern to western Taiwan. The hairtail fishing grounds were located in Yilan Bay off north-eastern Taiwan and the coastal waters off western Taiwan from $24.5^{\circ} \mathrm{N}$ (Figure 3a). The Japanese jack mackerel were caught in the waters off northern Taiwan, as part of the resources in the southern part of the East China Sea (Figure 3b).

The fishing grounds for neritic squids were spread widely, with hot spots in the northern and west-central waters in the Taiwan Strait and the southwestern waters off Taiwan (Figure 3c). The sakura shrimp, Taiwan mauxia shrimp, and larval anchovy were distributed close to the coast of southern Taiwan (Kaohsiung and Pingtung; Figure 3d-f). Sakura shrimp and larval anchovy indicated the hot-spot fishing grounds in Yilan Bay (Figure 3e,f). 
Table 4. Summary of the major harvest species caught in the trawl fishery from 2013-2019. Cumulative percentages are shown for total catch of the top six species, which accounted for more than $55 \%$.

\begin{tabular}{cccc}
\hline Common Name & Catch (ton) & Catch $\mathbf{\%}^{\mathbf{2}}$ & Cumulative $\mathbf{\%}^{\mathbf{2}}$ \\
\hline Hairtails & 9335 & 15.7 & 15.7 \\
Japanese Jack Mackerel & 6271 & 10.5 & 26.2 \\
Sakura Shrimp & 5410 & 9.1 & 35.3 \\
Neritic Squid & 4691 & 7.9 & 43.2 \\
Taiwan Mauxia Shrimp & 4245 & 7.1 & 50.3 \\
Larval Anchovy & 3433 & 5.8 & 56.1 \\
Thick-Shell Shrimp & 1771 & 3.0 & 59.1 \\
Pacific Rudderfish & 1630 & 2.7 & 61.8 \\
Silver Croaker & 1523 & 2.6 & 64.4 \\
Spear Shrimp & 1485 & 2.5 & 66.9 \\
Other 124 Species & 19,715 & 33.1 & - \\
\hline 134 Species Catches & 59,509 & - & - \\
\hline 19 Unclassified Species Catches & 35,875 & - & - \\
\hline Total & 95,384 & - & \\
\hline
\end{tabular}

${ }^{2}$ Only calculated with 134-species catches that excluded 19 catches of unclassified species.

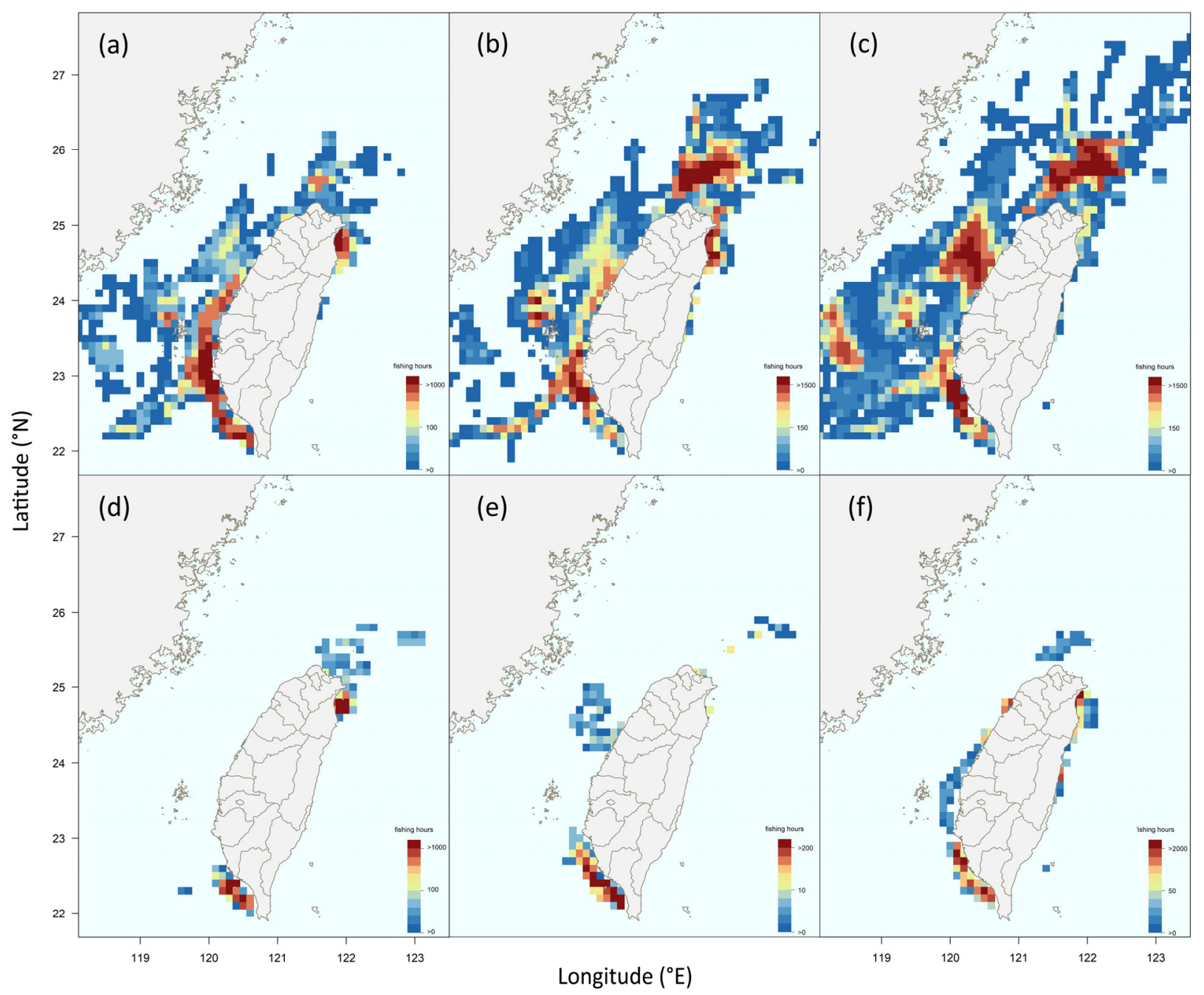

Figure 3. Fishing distributions, as estimated using data from VDR for trips in specific catch métier; results are shown for (a) hairtails, (b) Japanese jack mackerel, (c) neritic squid, (d) sakura shrimp, (e) Taiwan mauxia shrimp, and (f) larval anchovy fishing grounds for the Taiwanese offshore and coastal trawl fishery. 


\section{Discussion}

Trawler operations are widely spread along the shelf of the southern East China Sea and Taiwan Strait (TS). However, considerable fishing efforts are concentrated in specific waters where oceanographic conditions are complex and associated with a high primary production [50,51]. At the edge of the continental shelf, northeast of Taiwan $\left(25-26^{\circ} \mathrm{N}\right.$; Figure 1), the Kuroshio Current, Taiwan Strait Warm Current, and Mainland China Coastal Current (CCC) are encountered seasonally, leading to high fishing exploitation of the neritic squid [4,52] and pelagic species (e.g., Japanese jack mackerel), as observed in this study. Similar patterns were found in the water of TS, particularly the Kaopin Submarine Canyon [53-55], resulting in diverse fishing patterns and multiple fishing strategies in the coastal and offshore trawl fisheries of Taiwan.

The data obtained from commercial fishery-dependent surveys were explored in this study. High-resolution and extensive spatial and temporal information could be used as the fundamental basis for implementation in fishery management $[1,2,56]$. The two main fishery monitoring and surveillance systems developed in Taiwan, namely the VDR system and the port sampling observer program, were demonstrated to be able to provide a high quality of information from the monitoring system, which covered more than $70 \%$ of the trips during the last decade. This set of big data, with long-term series information, integrated information regarding target species, gear type, fishing activities, and the spatial distribution of fishery resources, covering a large area of the fishing ground for trawl fisheries. This study was the first to interpret the structure of a mixed trawl fishery, with all of the available fishery information, and using a catch métier approach to illustrate the hot-spot distributions for the target groups.

In the present study, a two-step approach was sued to deal with the set of big data of the landings per trip. The clustering could gathered similar characteristics (catch composition) among the fishing trips and provided insights into the resources exploited. The hierarchical clustering performed well and efficiently, providing a robust interpretation of the fishery structure of the trawl fisheries; to the best of our knowledge, similar analysis was conducted in previous studies $[6,7,19,20,23,25-34,40]$. This approach to defining the fleet structure and catch métier in mixed fisheries was applied successfully. Differently from the traditional clustering approach, this hierarchical clustering framework provided a novel choice for classifying the relationship of the catch métiers [57].

Moreover, we used a two-step approach to solve the issue of different data resolutions and classify the appropriate clusters, which represented the catch compositions of the trawl fisheries well. The initial data mining procedure could gather information within the cluster by similar features. However, similar species compositions from large clusters might result from diverse fishing strategies, without an obvious tendency towards the target group; for example, six sub-clusters were separated from Cluster IV in the second step of clustering based on high-resolution data (species). This was because the information of the specific catch tendencies (target group) was insufficient to be used to identify the trips in the first step of clustering. The shrimp resources in Cluster $\mathrm{V}$ were a dominant fishery component in the trawlers in Taiwan, but diverse fishing strategies existed in the trawl fisheries in this study. This could be expected, and it further demonstrated that the catch métiers consisted of five target shrimp species in these fisheries.

The catch métiers defined in this study performed well in terms of identifying the target groups by specific trawl gear, as shown in Table 3. Larval anchovy, Taiwan mauxia shrimp, and sakura shrimp were indicated as the main target species in midwater trawl fisheries, according to the specific fishing strategies for trawler fishing in Taiwan [8]. We also interviewed the observers at the fishing ports with the largest production of hairtails and confirmed that the pair trawlers targeted hairtails during the fishing season by using a specific trawl net, as shown and suggested by the catch métier of hairtails. The estimated fishing process distributions corresponded well with the actual trawl fishing grounds for the trips of the sakura shrimp and Taiwan mauxia shrimp métier (Figure 3d,e). Moreover, the hot spots located on the northeastern and southwestern coast of Taiwan confirmed 
the high production and prosperous fishing in these counties. The results from this study could be used to infer and trace back the fishing grounds and operation patterns associated with diverse fishing strategies and complex landing species [21,28,58-60].

We summarized the targeting groups for highly exploited fishery resources in Taiwan used by the trawl fisheries on the basis of long-term data and the catch métier approach (Table 3). The fishermen targeted species depending on their experience, by season, and by area in advance, and shifted their fishing activity and tendencies accordingly [58,61-64]. The trip with the catch métier could be used as a proxy for monitoring coastal and offshore fishery resources [7]. Moreover, the fishing footprints obtained using VDR in highresolution data tracking, such as automatic identification systems (AIS) and vessel monitoring systems (VMS), could be used to assess the data coverage and fleet dynamics of fishing activity [65-67]. In this study, we found that fishing strategies and tactics varied by season, vessel size, gear type, and spatial ground in coastal waters, particularly in the case of small-scale vessels $[18,20]$. In addition, we aimed to illustrate the successful use of developing catch profiles or components according to a "métier unit," which would be useful to understand specific fishing strategies and correlate the relationships among tempo-spatial metrics of fishery structure, with social and economic variables in a next step.

\section{Conclusions}

A management schema of multispecies and mixed fisheries could be based on the single-stock assessments combined with the knowledge about the associated species composition. For the sustainable development of coastal and offshore trawl fisheries, we suggest that the fishery resources of hairtails, Japanese jack mackerel, larval anchovy, sakura shrimp, Taiwan mauxia shrimp, and neritic squid in trawl fisheries be managed appropriately with this catch métier-based approach, in order to maintain the production. In response to the requirements for monitoring, control, and surveillance (MCS) of fishery activities, the amount of information regarding fishing activity has increased notably and rapidly in recent years. It would be a challenge to uncover the fishing activity using conventional approaches, which emphasizes the need to develop novel analytic approaches to handle the information from the fishing activity process more effectively and efficiently. Nevertheless, the monitoring of the exploitation status, as indicated by the catch métier defined in this study, could help to improve the stock assessment and fishery management measures for ecosystem consideration.

Supplementary Materials: The following are available online at https:/ / www.mdpi.com/article/10 $.3390 /$ jmse9050480/s1, Figure S1: The percentage of landing data that match with the VDR records for trips by fishing gear in the study period, Figure S2: The scree plot of within cluster distances sum of squares, Figure S3: ANOSIM plot of the (a) 6 target group clusters and (b) 18 catch métiers with statistic $\mathrm{R}$ and $p$-value based on catch composition in landing data, Figure S4: The diagram of change of target group composition profiles from different cluster numbers. The 6 clusters were determined to clearly separate the trips that main target Cephalopods (code 15) and Miscellaneous (code 22), Figure S5: The diagram of the two-step clustering process. We determined 6 clusters interpreted the group of trips to target homogenous fishery resources (low-resolution data of target group) in the first step. Given the huge number of trips and fuzzy hidden catch information in Clusters IV, $\mathrm{V}$, and VI, cluster analysis was conducted using species composition in the second step, Table S1: The species for the target group of the trawl fishery in coastal and offshore water off Taiwan. Target groups aggregated homogeneous species according to taxonomy (target group code 1-21). Species with low economic value but frequently caught are shown in the miscellaneous group (code 22). Main fishery resources are presented for the trawl fishery, Table S2: Fishing speed criterion by gear type for the trawl fishery in Taiwan, Table S3: The total sum of square within the groups and the difference (percentage) for various groups of clusters. Six clusters were determined in this study.

Author Contributions: Conceptualization, Y.-J.L., N.-J.S., H.-T.L., W.W.-Y.H. and C.-H.L.; Data curation, Y.-J.L., N.-J.S., H.-T.L., W.W.-Y.H. and C.-H.L.; Formal analysis, Y.-J.L.; Funding acquisition, C.-H.L.; Project administration, C.-H.L.; Supervision, N.-J.S. and C.-H.L.; Visualization, Y.-J.L., N.J.S., H.-T.L., W.W.-Y.H. and C.-H.L.; Writing-original draft, Y.-J.L. and H.-T.L.; Writing-review 
\& editing, Y.-J.L., N.-J.S. and C.-H.L. All authors have read and agreed to the published version of the manuscript.

Funding: This work was funded by Fisheries agency in Taiwan under coastal fisheries research projects (110AS-6.1.2-FA-F1(2), 110AS-6.1.2-FA-F2(1), 109AS-1.2.2-FA-F4, 109AS-9.2.1-FA-F1(1), 109AS9.2.3-FA-F1(4), 108AS-9.2.3-FA-F1(1), 108AS-9.2.4-FA-F1(1)).

Institutional Review Board Statement: Not applicable.

Informed Consent Statement: Not applicable.

Data Availability Statement: Not applicable.

Acknowledgments: We would like to thank Hsiao-Ting Huang for her kind and professional help with the VDR data analysis. We would like to express our sincere gratitude for the reliable supports offered by Taiwan Ocean Conservation and Fisheries Sustainability Foundation.

Conflicts of Interest: The authors declare no conflict of interest.

\section{References}

1. Anderson, C.M.; Krigbaum, M.J.; Arostegui, M.C.; Feddern, M.L.; Koehn, J.Z.; Kuriyama, P.T.; Morrisett, C.; Allen Akselrud, C.I.; Davis, M.J.; Fiamengo, C.; et al. How commercial fishing effort is managed. Fish Fish. 2019, 20, 268-285. [CrossRef]

2. Liao, C.P.; Huang, H.W.; Lu, H.J. Fishermen's perceptions of coastal fisheries management regulations: Key factors to rebuilding coastal fishery resources in Taiwan. Ocean Coast. Manag. 2019, 172, 1-13. [CrossRef]

3. Nomura, K.J.; Kaplan, D.M.; Beckensteiner, J.; Scheld, A.M. Comparative analysis of factors influencing spatial distributions of marine protected areas and territorial use rights for fisheries in Japan. Mar. Policy 2017, 82, 59-67. [CrossRef]

4. Liao, C.H.; Lan, K.W.; Ho, H.Y.; Wang, K.Y.; Wu, Y.L. Variation in the catch rate and distribution of swordtip squid Uroteuthis edulis associated with factors of the oceanic environment in the Southern East China Sea. Mar. Coast. Fish. 2018, 10, $452-464$. [CrossRef]

5. Jennings, S. Indicators to support an ecosystem approach to fisheries. Fish Fish. 2015, 6, 212-232. [CrossRef]

6. Lucey, S.M.; Fogarty, M.J. Operational fisheries in New England: Linking current fishing patterns to proposed ecological production units. Fish. Res. 2013, 141, 3-12. [CrossRef]

7. Quetglas, A.; Merino, G.; Ordines, F.; Guijarro, B.; Garau, A.; Grau, A.M.; Oliver, P.; Massutí, E. Assessment and management of western Mediterranean small-scale fisheries. Ocean Coast. Manag. 2016, 133, 95-104. [CrossRef]

8. Zhou, Y.X.; Su, W.C. Atlas of Fishing Gear and Methods in Taiwan, 1st ed.; Fisheries Agency, Council of Agriculture: Taipei, Taiwan, 2002. (In Chinese)

9. FA. Fisheries Statistical Yearbook-Taiwan, Kinmen and Matsu Area, 2019; Fisheries Agency, Council of Agriculture: Taipei, Taiwan, 2020. (In Chinese)

10. Oberle, F.K.; Storlazzi, C.D.; Hanebuth, T.J. What a drag: Quantifying the global impact of chronic bottom trawling on continental shelf sediment. J. Mar. Syst. 2016, 159, 109-119. [CrossRef]

11. Depestele, J.; Ivanović, A.; Degrendele, K.; Esmaeili, M.; Polet, H.; Roche, M.; Summerbell, K.; Teal, L.R.; Vanelslander, B.; O’Neill, F.G. Measuring and assessing the physical impact of beam trawling. ICES J. Mar. Sci. 2016, 73, i15-i26. [CrossRef]

12. Chang, S.K. From subsidy evaluation to effort estimation: Advancing the function of voyage data recorders for offshore trawl fishery management. Mar. Policy 2016, 74, 99-107. [CrossRef]

13. Kuan, J.C. Evaluation of Vessels Reduction Program of Taiwan Coastal-Offshore Fisheries. Ph.D. Thesis, National Sun Yat-sen University, Kaohsiung City, Taiwan, 2003. (In Chinese).

14. Ho, C.H.; Chen, J.L.; Nobuyuki, Y.; Lur, H.S.; Lu, H.J. Mitigating uncertainty and enhancing resilience to climate change in the fisheries sector in Taiwan: Policy implications for food security. Ocean Coast. Manag. 2016, 130, 355-372. [CrossRef]

15. Fisheries Management and Practice of Responsible Fisheries in the Coastal and Offshore Fisheries. Available online: https://www. fa.gov.tw / en /CoastalFisheries / content.aspx?id=1\&chk=10824b1b-9adf-4a08-ae15-8d34a8ef2572\&param=pn\%3d1 (accessed on 1 March 2021).

16. Laurent Singh, C.M.; Aguiar-Santos, J.; Gondim Ferreira, E.J.; Evaristo, E.D.C.; Freitas, C.E.D.C. Spatial and Temporal Distribution of a Multiple Gear Fishing Fleet Exploiting the Caribbean Sea and North Brazil Shelf Large Marine Ecosystems. Mar. Coast. Fish. 2020, 12, 100-112. [CrossRef]

17. Prestrelo, L.; Oliveira, R.; Vianna, M. A new proposal to classify small fishing vessels to improve tropical estuarine fishery management. Fish. Res. 2019, 211, 100-110. [CrossRef]

18. Mendoza-Portillo, F.J.; Ramírez-Rodríguez, M.; Vargas-López, V. Interactions of small-scale fisheries in Mexico's northwest Pacific. Lat. Am. J. Aquat. Res. 2020, 48, 94-105. [CrossRef]

19. Salas, S.; Torres-Irineo, E.; Coronado, E. Towards a métier-based assessment and management approach for mixed fisheries in Southeastern Mexico. Mar. Policy 2019, 103, 148-159. [CrossRef]

20. Chen, C.S.; Lee, B.W. Trends in trawl-targeted species landings off northern Taiwan and effects of fishing and environmental factors. Fish. Res. 2013, 79, 163-176. [CrossRef] 
21. Duarte, R.; Azevedo, M.; Afonso-Dias, M. Segmentation and fishery characteristics of the mixed-species multi-gear Portuguese fleet. ICES J. Mar. Sci. 2009, 66, 594-606. [CrossRef]

22. Liao, C.H.; Huang, H.T.; Lee, Y.J. Analysis of Taiwan Coastal and Offshore Fisheries Activities; Report of Research Project 109AS-9.2.1FA-F1(1); Fisheries Agency: Kaohsiung, Taiwan, 2020; 242p. (In Chinese)

23. Castro, J.; Marín, M.; Pierce, G.J.; Punzón, A. Identification of métiers of the Spanish set-longline fleet operating in non-Spanish European waters. Fish. Res. 2011, 107, 100-111. [CrossRef]

24. Natale, F.; Carvalho, N.; Paulrud, A. Defining small-scale fisheries in the EU on the basis of their operational range of activity The Swedish fleet as a case study. Fish. Res. 2015, 164, 286-292. [CrossRef]

25. He, X.; Bigelow, K.A.; Boggs, C.H. Cluster analysis of longline sets and fishing strategies within the Hawaii-based fishery. Fish Res. 1997, 31, 147-158. [CrossRef]

26. Jiménez, M.P.; Sobrino, I.; Ramos, F. Objective methods for defining mixed-species trawl fisheries in Spanish waters of the Gulf of Cádiz. Fish. Res. 2004, 67, 195-206. [CrossRef]

27. Tzanatos, E.; Dimitriou, E.; Katselis, G.; Georgiadis, M.; Koutsikopoulos, C. Composition, temporal dynamics and regional characteristics of small-scale fisheries in Greece. Fish. Res. 2005, 73, 147-158. [CrossRef]

28. Katsanevakis, S.; Maravelias, C.D.; Kell, L.T. Landings profiles and potential métiers in Greek set longliners. ICES J. Mar. Sci. 2010, 67, 646-656. [CrossRef]

29. Castro, J.; Punzón, A.; Pierce, G.J.; Marín, M.; Abad, E. Identification of métiers of the Northern Spanish coastal bottom pair trawl fleet by using the partitioning method CLARA. Fish. Res. 2010, 102, 184-190. [CrossRef]

30. Davie, S.; Lordan, C. Definition, dynamics and stability of métiers in the Irish otter trawl fleet. Fish. Res. 2011, 111, 145-158. [CrossRef]

31. Deporte, N.; Ulrich, C.; Mahévas, S.; Demanèche, S.; Bastardie, F. Regional métier definition: A comparative investigation of statistical methods using a workflow applied to international otter trawl fisheries in the North Sea. ICES J. Mar. Sci. 2012, 69, 331-342. [CrossRef]

32. Tzanatos, E.; Somarakis, S.; Tserpes, G.; Koutsikopoulos, C. Identifying and classifying small-scale fisheries métiers in the Mediterranean: A case study in the Patraikos Gulf, Greece. Fish. Res. 2006, 81, 158-168. [CrossRef]

33. Palmer, M.; Quetglas, A.; Guijarro, B.; Moranta, J.; Ordines, F.; Massutí, E. Performance of artificial neural networks and discriminant analysis in predicting fishing tactics from multispecific fisheries. Can. J. Fish. Aquat. Sci. 2009, 66, $224-237$. [CrossRef]

34. Monroy, C.; Salas, S.; Bello-Pineda, J. Dynamics of fishing gear and spatial allocation of fishing effort in a multispecies fleet. N. Am. J. Fish. Manag. 2010, 30, 1187-1202. [CrossRef]

35. Maynou, F.; Recasens, L.; Lombarte, A. Fishing tactics dynamics of a Mediterranean small-scale coastal fishery. Aquat. Living Resour. 2011, 24, 149-159. [CrossRef]

36. Arce-Acosta, M.; Ramírez-Rodríguez, M.; De-la-Cruz-Agüero, G. Small scale fisheries operative units in the west central region of the Gulf of California, Mexico. Ocean Coast. Manag. 2018, 160, 58-63. [CrossRef]

37. Ulrich, C.; Wilson, D.C.; Nielsen, J.R.; Bastardie, F.; Reeves, S.A.; Andersen, B.S.; Eigaard, O.R. Challenges and opportunities for fleet-and métier-based approaches for fisheries management under the European Common Fishery Policy. Ocean Coast. Manag. 2012, 70, 38-47. [CrossRef]

38. Iriondo, A.; García, D.; Santurtún, M.; Castro, J.; Quincoces, I.; Lehuta, S.; Mahévas, S.; Marchal, P.; Tidd, A.; Ulrich, C. Managing mixed fisheries in the European Western Waters: Application of Fcube methodology. Fish. Res. 2012, 134, 6-16. [CrossRef]

39. Maravelias, C.D.; Damalas, D.; Ulrich, C.; Katsanevakis, S.; Hoff, A. Multispecies fisheries management in the Mediterranean Sea: Application of the Fcube methodology. Fish. Manage. Ecol. 2012, 19, 189-199. [CrossRef]

40. Cardoso, I.; Moura, T.; Mendes, H.; Silva, C.; Azevedo, M. An ecosystem approach to mixed fisheries: Technical and biological interactions in the Portuguese multi-gear fleet. ICES J. Mar. Sci. 2015, 72, 2618-2626. [CrossRef]

41. Tsai, P.C.; Yeh, H.M.; Chan, B.K.K.; Chan, T.Y. Comparison between the catch composition of the French and ORE type beam trawls on deep-sea decapod crustaceans: Implications for quantitative sampling of the deep-sea decapod biodiversity. Crustaceana 2009, 82, 565-591. [CrossRef]

42. Wang, T.W.; Chan, T.Y.; Chan, B.K. Diversity and community structure of decapod crustaceans at hydrothermal vents and nearby deep-water fishing grounds off Kueishan Island, Taiwan: A high biodiversity deep-sea area in the NW Pacific. Bull. Mar. Sci. 2013, 89, 505-528. [CrossRef]

43. Russo, T.; Parisi, A.; Cataudella, S. Spatial indicators of fishing pressure: Preliminary analyses and possible developments. Ecol. Indic. 2013, 26, 141-153. [CrossRef]

44. Natale, F.; Gibin, M.; Alessandrini, A.; Vespe, M.; Paulrud, A. Mapping fishing effort through AIS data. PLoS ONE 2015, 10, e0130746. [CrossRef]

45. Ferrà, C.; Tassetti, A.N.; Grati, F.; Pellini, G.; Polidori, P.; Scarcella, G.; Fabi, G. Mapping change in bottom trawling activity in the Mediterranean Sea through AIS data. Mar. Policy 2018, 94, 275-281. [CrossRef]

46. Tan, P.N.; Steinbach, M.; Kumar, V. Data mining cluster analysis: Basic concepts and algorithms. In Introduction to Data Mining; Pearson Addison-Wesley: Boston, MA, USA, 2013; pp. 488-568.

47. RStudio Team. RStudio: Integrated Development Environment for R; RStudio, PBC: Boston, MA, USA, 2020; Available online: http:/ / www.rstudio.com/ (accessed on 1 March 2021). 
48. Ward, J.H. Hierarchical grouping to optimize an objective function. J. Am. Stat. Assoc. 1963, 58, 236-244. [CrossRef]

49. Clarke, K.R. Non-parametric multivariate analyses of changes in community structure. Austral Ecol. 1993, 18, 117-143. [CrossRef]

50. Liang, W.D.; Tang, T.Y.; Yang, Y.J.; Ko, M.T.; Chuang, W.S. Upper-ocean currents around Taiwan. Deep Sea Res. Part II Top. Stud. Oceanogr. 2003, 50, 1085-1105. [CrossRef]

51. Lan, K.W.; Lian, L.J.; Li, C.H.; Hsiao, P.Y.; Cheng, S.Y. Validation of a Primary Production Algorithm of Vertically Generalized Production Model Derived from Multi-Satellite Data around the Waters of Taiwan. Remote Sens. 2020, 12, 1627. [CrossRef]

52. Wang, K.Y.; Chang, K.Y.; Liao, C.H.; Lee, M.A.; Lee, K.T. Growth strategies of the swordtip squid, Uroteuthis edulis, in response to environmental changes in the southern East China Sea-A cohort analysis. Bull. Mar. Sci. 2013, 89, 677-698. [CrossRef]

53. Huh, C.A.; Lin, H.L.; Lin, S.; Huang, Y.W. Modern accumulation rates and a budget of sediment off the Gaoping (Kaoping) River, SW Taiwan: A tidal and flood dominated depositional environment around a submarine canyon. J. Mar. Syst. 2009, 76, 405-416. [CrossRef]

54. Wu, Y.L.; Lee, M.A.; Chen, L.C.; Chan, J.W.; Lan, K.W. Evaluating a Suitable Aquaculture Site Selection Model for Cobia (Rachycentron canadum) during Extreme Events in the Inner Bay of the Penghu Islands, Taiwan. Remote Sens. 2020, 12, 2689. [CrossRef]

55. Tseng, H.C.; You, W.L.; Huang, W.; Chung, C.C.; Tsai, A.Y.; Chen, T.Y.; Lan, K.W.; Gong, G.C. Seasonal Variations of Marine Environment and Primary Production in the Taiwan Strait. Front. Mar. Sci. 2020, 7, 38. [CrossRef]

56. Pennino, M.G.; Conesa, D.; Lopez-Quilez, A.; Munoz, F.; Fernández, A.; Bellido, J.M. Fishery-dependent and-independent data lead to consistent estimations of essential habitats. ICES J. Mar. Sci. 2016, 73, 2302-2310. [CrossRef]

57. Parsa, M.; Emery, T.J.; Williams, A.J.; Nicol, S. A robust métier-based approach to classifying fishing practices within commercial fisheries. Front. Mar. Sci. 2020, 7, 974. [CrossRef]

58. Palmer, M.; Tolosa, B.; Grau, A.M.; del Mar Gil, M.; Obregón, C.; Morales-Nin, B. Combining sale records of landings and fishers knowledge for predicting métiers in a small-scale, multi-gear, multispecies fishery. Fish. Res. 2017, 195, 59-70. [CrossRef]

59. Leleu, K.; Pelletier, D.; Charbonnel, E.; Letourneur, Y.; Alban, F.; Bachet, F.; Boudouresque, C.F. Métiers, effort and catches of a Mediterranean small-scale coastal fishery: The case of the Côte Bleue Marine Park. Fish. Res. 2014, 154, 93-101. [CrossRef]

60. Roditi, K.; Antoniadou, C.; Matsiori, S.; Halkos, G.; Vafidis, D. Longline métiers and associated economic profiles in eastern Mediterranean fisheries: The case study of Kalymnos Island (South Aegean Sea). Ocean Coast. Manag. 2020, 195, 105275. [CrossRef]

61. Wang, K.Y.; Lee, K.T.; Liao, C.H. Age, growth and maturation of swordtip squid (Photololigo edulis) in the southern East China Sea. J. Mar. Sci. Technol. 2020, 18, 99-105.

62. Shih, N.T.; Hsu, K.C.; Ni, I.H. Age, growth and reproduction of cutlassfishes Trichiurus spp. in the southern East China Sea. J. Appl. 2011, 27, 1307-1315. [CrossRef]

63. Lu, H.J.; Chen, C.C.; Cheng, J.C. Age and Growth Study of the Jack Mackerel (Trachurus japonicus) in the Northeatern Waters off Taiwan. J. Mar. Sci. Technol. 2013, 21, 31-40.

64. Wang, S.B.; Chen, Y.L.; Liu, K.M. Recent observations on the change of reproductive traits of Japanese butterfish, Psenopsis anomala, in waters off northeastern Taiwan. J. Mar. Sci. Technol. 2015, 23, 249-257.

65. Maina, I.; Kavadas, S.; Katsanevakis, S.; Somarakis, S.; Tserpes, G.; Georgakarakos, S. A methodological approach to identify fishing grounds: A case study on Greek trawlers. Fish. Res. 2016, 183, 326-339. [CrossRef]

66. Russo, T.; Carpentieri, P.; Fiorentino, F.; Arneri, E.; Scardi, M.; Cioffi, A.; Cataudella, S. Modeling landings profiles of fishing vessels: An application of Self-Organizing Maps to VMS and logbook data. Fish. Res. 2016, 181, 34-47. [CrossRef]

67. De Angelis, P.; D'Andrea, L.; Franceschini, S.; Cataudella, S.; Russo, T. Strategies and trends of bottom trawl fisheries in the Mediterranean Sea. Mar. Policy 2020, 118, 104016. [CrossRef] 